\title{
CORTICAL MECHANISMS OF REGULATION OF LITHIUM CONTENT IN BLOOD OF COWS DEPENDING ON THE SEASONS
}

\author{
O. V. ZHURENKO, Doctor of Veterinary Sciences, \\ Department of Animal Biochemistry and Physiology \\ named after Academician M. F. Gulyi \\ https://orcid.org/0000-0002-4933-0372 \\ V. I. KARPOVSKYI, Doctor of Veterinary Sciences, Professor, \\ Department of Animal Biochemistry and Physiology \\ named after Academician M. F. Gulyi \\ https://orcid.org/0000-0003-3858-0111 \\ V. V. ZHURENKO, Candidate of Veterinary Sciences, \\ Department of Animal Biochemistry and Physiology \\ named after Academician M. F. Gulyi \\ https://orcid.org/ 0000-0003-2097-9212 \\ National University of Life and Environmental Sciences of Ukraine, Kyiv, Ukraine \\ E-mail: Zhurenko-lena@ukr.net
}

\begin{abstract}
The behavior of farm animals, especially cattle, is an important economic and useful feature, which significantly facilitates the operating conditions and production of livestock products. The parameters of the nervous system in cattle determine its behavior in various situations, including keeping in the pen, herding, and milking. The optimal content of minerals in the body leads to the normal course of metabolic processes and high productivity. Based on the results of studying the conditioned reflex activity, four experimental groups were formed. Whole blood, serum, and blood cells were used for laboratory analysis. Based on the results of the analysis of variance of the lithium content in different blood fractions of cows, no reliable interaction between the typological features of the nervous system and the season has been established. The mobility of nervous processes, regardless of the season, is reliably associated with the lithium content in whole blood, blood cells, and blood serum $(r=0.15-0.22)$. Along with this, the parameter of the lithium transmembrane potential (Licell/Liserum) is reliably associated mainly with the strength and balance of nervous processes in cows in the warm season $-r=0.62-0.76(P<0.05-0.01)$. A significant dependence on the type of higher nervous activity in cows and the lithium content in blood serum $(F=13.2>F U=3.01 ; P<0.001)$, whole blood $(F=14.8>F U=3.01 ; P<0.001)$, and blood cells $(F=23.1>F U=3.01 ; P<0.001)$ is established. In cows with a weak type of higher nervous activity, the lithium content in blood serum and its cells was lower by $12.1 \%(P<0.05)$ and $18.0 \%(P<0.05)$, respectively, compared with the parameters of cows with a strong balanced mobile type.
\end{abstract}

Keywords: higher nervous activity, micronutrients, types of higher nervous activity, nervous processes 


\section{Introduction}

Over the past decades, there have been fundamental changes in the field of world veterinary medicine, which make it possible to assert that without the application of advances in biochemistry, physiology, microbiology, and other disciplines, it is impossible to fully realize the productive and breeding qualities of animals. Microbiological, biochemical, and physiological processes in the body of animals determine the entire course of individual development in animals, its existence, and the productivity development (Avtsyn et al., 1991). The behavior of farm animals, especially cattle, is an important economically useful feature, which significantly facilitates the operating conditions and production of livestock products (Gapon $\&$ Yashchenko, 2005). The parameters of the nervous system in cattle determine its behavior in various situations, including keeping in the pen, herding, and milking. The use of knowledge in technology on the temperament of animals, the type of their higher nervous activity, and the state of the autonomic nervous system due to both heredity and environmental impact, creates the preconditions for the full realization of its genetic potential.

\section{Analysis of recent researches and publications}

The type of higher nervous activity in animals determines not only the nature of the adaptive reactions in the organism but also the main characteristics of cortical processes affecting various metabolism levels, which is reflected in the economically useful properties of productive animals (McDowell, 2003). The optimal mineral content in the body leads to the normal course of metabolic processes and high productivity (Hrushanska et al., 2017). The value of mineral nutrition in cattle depends on animal's provision with essential micronutrients that are part in the structure of many enzymes or are their activators, taking a leading role in redox reactions (Guyot et al., 2012). However, insufficient attention is paid to the studying of individual features of mineral homeostasis in the body of productive cows in intact and stressful state (McDowell, 2003; Zinko, 2017). The determination of the individual features of higher nervous activity in animals allows understanding deeper the cortical mechanisms of regulation of various physiological functions, creating the preconditions for targeted exposure (Pogorlov, 2010; Danchuk et al., 2017). Micronutrients play a significant biological role despite their low content in the body (Byts, 2010; Gromova et al., 2010). In addition to the general positive effect on the growth and development processes, the specific effect of several micronutrients on the most important physiological processes has been established, and their importance is explained by the fact that they come into a close relationship with biologically active substances - hormones and vitamins (Zakharenko, 2004). Lithium is a very valuable and important micronutrient for animals. This element affects the serotonin release and receptor sensitivity, as well as modulates the norepinephrine action (Skalny, 2004; Kalyn, 2011). Today it is believed that the mechanism of lithium action is associated with the depletion of inositol reserves in the central nervous system (Marushko, 2013). It is known from literature sources that lithium has the ability to reduce the excitability of the central nervous system by releasing magnesium from cellular "depots" and inhibiting the transmission of nerve impulses; regulate sodium transport in nerve and muscle cells. 


\section{Materials and methods of research}

The experiments were carried out on cows of the Ukrainian black-and-white dairy breed of the $2-3$ rd lactation. The types of higher nervous activity were determined by the express method for assessing conditioned reflex activity in cattle, which allows reliably assert that the animal belongs to the corresponding type of higher nervous activity in 20-30 minutes of the experiment. The conditions of use, keeping, diet, and feeding frequency were the same in all experimental animals. To study the conditioned reflex activity, 100 cows were selected. The strength, balance, and mobility of the nervous processes were determined in all animals using a modified method. The method is based on the observance of the behavior in an animal in a group and individual pen, the reaction of the animal to the experimenter, the reaction of a hungry animal to feeding, unexpected sensory stimuli, and the formation of conditioned reflexes.

The typological characteristics of the nervous system were determined by three tests analysis.

According to the results of studying the conditioned reflex activity, 4 experimental groups were formed. The first group included animals with a strong balanced mobile type, the second - a strong balanced inert type, the third - a strong unbalanced type, and the fourth - a weak type of higher nervous activity. Blood from cattle was obtained from the jugular vein. During blood sampling, the unnecessary abuse of the animal was avoided. Whole blood, serum, plasma, and blood cells were used for laboratory analysis. Blood from animals was collected in three test tubes. The first test tube contained the whole blood, the second was used to extract blood serum for analysis, and the third one - to obtain plasma and blood cells. To stabilize whole blood and to obtain plasma, three drops of $1 \%$ heparin solution were preliminarily introduced into the test tube. To obtain plasma, blood with the anticoagulant immediately after its collection was centrifuged at 2000-3000 rpm for 15-20 min, after which the plasma was poured into another tube. To obtain blood cells, the cell pellet was washed out three times in cold saline solution, followed by centrifugation at $3000 \mathrm{rpm}$ for $15 \mathrm{~min}$. To obtain blood serum, no anticoagulant was added. After blood sampling, the tube was left at room temperature until the serum was completely separated, after which manipulations were performed to obtain the serum following standard procedures. After preparing the samples, they were immediately sent to the laboratory in a cooler bag (Vlizlo et al., 2012).

To determine micro- and macronutrients, the samples are preliminarily mineralized by the method of dry or wet ashing. After ashing, acid extraction is carried out. In prepared samples, the elements are determined by atomic absorption spectrophotometry. Experimental research is consistent with the basic principles of the European Convention for the Protection of Vertebrate Animals used for Experimental and other Scientific Purposes (Strasbourg, 1986) and the Declaration on the Humane Treatment of Animals (Helsinki, 2000). The obtained digital data were processed statistically using the applied software package "Microsoft Office Excel 2013". The arithmetic mean value $(\mathrm{M})$ and its error $(\mathrm{m})$ were determined. The probability of differences in mean values was determined by the Student's test. Parameters changes were considered significant at $\mathrm{P}<0.05$ (including $\mathrm{P}<0.01$ and $\mathrm{P}<0.001$ ). In 
addition, correlation, regression, one and two-factor analysis of variance of the obtained results were carried out.

\section{Results of the research and their discussion}

Studies have shown that in animals with different types of higher nervous activity, the lithium content in blood serum, whole blood, and its cells did not exceed physiological limits and was $0.42-0.52 \mu \mathrm{g} / 100 \mathrm{ml}, 0.33-0.42 \mu \mathrm{g} / 100$ $\mathrm{ml}$, and $0.18-0.23 \mu \mathrm{g} / 100 \mathrm{ml}$, respectively (Table 1).

There were no significant differences in the lithium content in different blood fractions in cows with strong balanced mobile and strong balanced inert type of higher nervous activity in different seasons of the year. Also, the lithium content in different blood fractions in cows with different types of higher nervous activity in cold and warm seasons did not differ significantly.
In summer, in cows with a strong unbalanced type of higher nervous activity, the lithium content was lower by $15.7 \%$ $(\mathrm{P}<0.01), 17.5 \%(\mathrm{P}<0.05)$, and $19.1 \%$ $(\mathrm{P}<0.01)$ in serum, whole blood, and its cells, respectively, than in animals with a strong balanced mobile type. Whereas in winter, the lithium content in the blood serum, whole blood, and blood cells in cows of this type of higher nervous activity was lower by $8.9-11.6(\mathrm{P}<0.05-0.01)$, respectively, compared with the indicators in cows with a strong balanced mobile type.

In summer, cows with a weak type of higher nervous activity had lower lithium content in blood serum and its cells by $12.1 \%(\mathrm{P}<0.05)$ and $18.0 \%(\mathrm{P}<0.05)$, respectively, compared with the indicators of cows with a strong balanced mobile type. Whereas in winter, the lithium content in blood serum, whole blood, and blood cells in cows of this type of higher nervous activity was lower by $14.6-16.3 \%(\mathrm{P}<0.05-0.01)$, respectively, compared with the indicators of cows with a strong balanced mobile type.

\section{Lithium content in the blood of cows with different types of higher nervous activity depending on the season $(\mu \mathrm{g} / 100 \mathrm{ml} ; \mathrm{M} \pm \mathbf{m}, \mathbf{n}=5)$}

\begin{tabular}{|c|c|c|c|c|}
\hline \multirow[b]{2}{*}{ Substrate } & \multicolumn{4}{|c|}{ Type of higher nervous activity } \\
\hline & $\begin{array}{c}\text { Strong balanced } \\
\text { mobile }\end{array}$ & $\begin{array}{c}\text { Strong balanced } \\
\text { inert }\end{array}$ & $\begin{array}{c}\text { Strong } \\
\text { unbalanced }\end{array}$ & Weak \\
\hline \multicolumn{5}{|c|}{ Summer } \\
\hline Blood serum & $0.495 \pm 0.016$ & $0.523 \pm 0.015$ & $0.418 \pm 0.011^{* *}$ & $0.435 \pm 0.034 *$ \\
\hline Whole blood & $0.400 \pm 0.011$ & $0.421 \pm 0.014$ & $0.330 \pm 0.010^{*}$ & $0.345 \pm 0.027$ \\
\hline Blood cells & $0.223 \pm 0.006$ & $0.230 \pm 0.007$ & $0.180 \pm 0.004^{* *}$ & $0.183 \pm 0.012 *$ \\
\hline Licell/Liserum & $0.450 \pm 0.003$ & $0.440 \pm 0.009$ & $0.431 \pm 0.004^{*}$ & $0.421 \pm 0.008^{*}$ \\
\hline \multicolumn{5}{|c|}{ Winter } \\
\hline Serum & $0.488 \pm 0.009$ & $0.510 \pm 0.009$ & $0.443 \pm 0.009^{*}$ & $0.415 \pm 0.022 *$ \\
\hline Whole blood & $0.393 \pm 0.006$ & $0.413 \pm 0.009$ & $0.358 \pm 0.006^{*}$ & $0.335 \pm 0.017 *$ \\
\hline Blood cells & $0.215 \pm 0.003$ & $0.225 \pm 0.006$ & $0.19 \pm 0.004 * *$ & $0.180 \pm 0.008^{* *}$ \\
\hline Licell/Liserum & $0.441 \pm 0.007$ & $0.441 \pm 0.005$ & $0.430 \pm 0.015$ & $0.435 \pm 0.010$ \\
\hline
\end{tabular}

Note: significant differences compared to cows with a strong balanced mobile type of higher nervous activity at $* \mathrm{P}<0.05, * * \mathrm{P}<0.01$. 
2. Correlation ( $r$ ) of the lithium content in blood of cows with the main characteristics of nervous processes $(\mathrm{CU}, \mathrm{n}=16)$

\begin{tabular}{|l|c|c|c|c|}
\hline \multicolumn{2}{|c|}{$\begin{array}{l}\text { Indicator } \\
\text { Strength }\end{array}$} & \multicolumn{2}{c|}{ The main characteristics of nervous processes } \\
\cline { 2 - 5 } & Summer & 0.28 & $0.66^{* *}$ & 0.17 \\
\hline \multirow{2}{*}{ Blood serum } & Winter & 0.28 & $0.68^{* *}$ & 0.21 \\
\hline \multirow{2}{*}{ Whole blood } & Summer & 0.39 & $0.81^{* * *}$ & 0.22 \\
\cline { 2 - 5 } & Winter & 0.45 & $0.70^{* *}$ & 0.21 \\
\hline \multirow{2}{*}{ Blood cells } & Summer & $0.63^{* *}$ & $0.69^{* *}$ & 0.20 \\
\cline { 2 - 5 } & Winter & $0.65^{* *}$ & $0.71^{* *}$ & 0.15 \\
\hline \multirow{2}{*}{ Licell/Liserum } & Summer & $0.62^{*}$ & $0.76^{* * *}$ & 0.10 \\
\cline { 2 - 5 } & Winter & 0.08 & 0.30 & -0.22 \\
\hline
\end{tabular}

Note: indicators are significant at $* \mathrm{P}<0.05$, ** $\mathrm{P}<0.01$, *** $\mathrm{P}<0.001$.

Theratioofthelithiumcontentinblood cells to the blood serum $\left(\mathrm{Li}_{\text {cell }} / \mathrm{Li}_{\text {serum }}\right)$ in cows with different types of higher nervous activity was $0.42-0.45 \mathrm{CU}$. It should be noted that this indicator in the blood of cows with different types of higher nervous activity in the cold season did not differ significantly, however, in summer, in cows with strong unbalanced and weak type of higher nervous activity it was lower by $4.1 \%(\mathrm{P}<0.05)$ and $6.4 \%(\mathrm{P}<0.05)$, respectively.

The relationship between the main characteristics of nervous processes in cows and the lithium content in blood depending on the season has been established (Table 2).

The strength of nervous processes is directly related to the lithium content only in blood cells in summer $(\mathrm{r}=0.63$; $\mathrm{P}<0.01)$ and in winter $(\mathrm{r}=0.65$; $\mathrm{P}<0.01)$. Instead, the balance of nervous processes, depending on the season, is directly related to the lithium content in blood serum $-\mathrm{r}=0.66-0.68$ $(\mathrm{P}<0.05)$, whole blood $-\mathrm{r}=0.70-0.81$ $(\mathrm{P}<0.01-0.001)$, and blood cells $\mathrm{r}=0.69-0.71 \quad(\mathrm{P}<0.01)$. The mobility of nervous processes, regardless of the season, is significantly associated with the lithium content in whole blood, blood cells, and blood serum $(\mathrm{r}=0.15$ 0.22). Along with this, the indicator of the transmembrane potential of lithium $\left(\mathrm{Li}_{\text {cell }} / \mathrm{Li}_{\text {serum }}\right)$ is significantly associated with the strength and balance of nervous processes in cows in the warm season $-r=0.62-0.76(P<0.05-0.01)$. The strength of nervous processes in the warm season does not significantly limit the lithium content in blood $\left(\eta^{2} x=0.11-\right.$ 0.22 ), however, it significantly affects the ratio of the lithium content in blood cells and serum $-\eta^{2} x=0.30(P<0.05)$. Whereas in the cold season, the strength of nervous processes increases the effect on the lithium content in whole blood, serum, and blood cells to a significant level $-\eta^{2} x=0.39-0.42(\mathrm{P}<0.001)$. However, the existing influence of the strength of nervous processes on the ratio of lithium in the blood cells and serum in cows becomes insignificant $\left(\eta^{2} x=0.04\right)$.

The balance of nervous processes in cows in summer significantly affects the lithium content in blood serum $\eta^{2} x=0.54 \quad(\mathrm{P}<0.001)$, whole blood $\eta^{2} x=0.58 \quad(\mathrm{P}<0.001)$, and blood cells $-\eta_{x}^{2}=0.73(P<0.001)$. In winter, the balance of nervous processes retains a 


\section{Regression analysis of the dependence of the lithium content in blood of cows on the main characteristics of nervous processes $(C U ; n=16)$}

\begin{tabular}{|l|c|c|c|c|c|c|}
\hline \multirow{2}{*}{ Indicator } & \multicolumn{7}{|c|}{ The main characteristics of nervous processes } \\
\cline { 2 - 7 } & Strength & \multicolumn{2}{c|}{ Balance } & \multicolumn{2}{c|}{ Mobility } \\
\cline { 2 - 7 } & Summer & Winter & Summer & Winter & Summer & Winter \\
\hline \multicolumn{7}{|c|}{ Blood serum } \\
\hline Regression coefficient & 0.019 & $0.033^{* *}$ & $0.041^{* *}$ & $0.034^{* *}$ & 0.011 & 0.01 \\
\hline Coefficient of determination & 0.08 & $0.39^{* *}$ & $0.43^{* *}$ & $0.48^{* *}$ & 0.03 & 0.04 \\
\hline \multicolumn{7}{|c|}{ Whole blood } \\
\hline Regression coefficient & 0.016 & $0.028^{* *}$ & $0.036^{* *}$ & $0.027^{* *}$ & 0.011 & 0.006 \\
\hline Coefficient of determination & 0.08 & $0.42^{* *}$ & $0.47^{* *}$ & $0.5^{* *}$ & 0.04 & 0.02 \\
\hline \multicolumn{7}{|c|}{ Blood cells } \\
\hline Regression coefficient & 0.012 & $0.015^{*}$ & $0.024^{* * *}$ & $0.018^{* * *}$ & 0.007 & 0.002 \\
\hline Coefficient of determination & 0.15 & $0.38^{*}$ & $0.65^{* * *}$ & $0.58^{* *}$ & 0.05 & 0.01 \\
\hline \multicolumn{7}{|c|}{ Licell/Liserum } \\
\hline Regression coefficient & 0.008 & 0.002 & $0.012^{* *}$ & 0.006 & 0.004 & -0.004 \\
\hline Coefficient of determination & 0.2 & 0.01 & $0.49^{* *}$ & 0.09 & 0.05 & 0.05 \\
\hline
\end{tabular}

Note: indicators are significant at $* \mathrm{P}<0.05$, ** $\mathrm{P}<0.01$, *** $\mathrm{P}<0.001$.

significant effect on the lithium content in the blood of cows up to the $\eta^{2} \chi=0.64$ $0.71(\mathrm{P}<0.001)$. The mobility of nervous processes does not significantly affect the lithium content in serum, whole blood, and cells of cows regardless of the season $\left(\eta^{2} x=0.08-0.17\right)$.

It should be noted that the ratio of lithium content in cells and blood serum in summer is significantly limited by the strength, balance, and mobility of nervous processes $-\eta^{2}{ }^{2}=0.27-0.37$ $(\mathrm{P}<0.05)$, while in winter this effect becomes insignificant $\left(\eta_{\chi}^{2}=0.02-0.06\right)$.

Regression analysis established the dependence of the lithium content on the mobility of nervous processes in cows (Table 3 ).

On the other hand, regardless of the season, when the balance of nervous processes changes by one unit, the lithium content in whole blood, blood cells, and its serum changes in the same way by
$0.02-0.04 \mu \mathrm{g} / 100 \mathrm{ml}(\mathrm{P}<0.01-0.001)$. The coefficient of determination of the strength of nervous processes with the content of this micronutrient indicates that $43-65 \%(\mathrm{P}<0.01-0.001)$ of variations in its content in different blood fractions are due to the variability of indicators of nervous process balance.

Unlike it, only in winter, when the strength of the nervous processes changes by one unit, the lithium content in different blood fractions changes in the same way by $0.02-0.03 \mathrm{mg} / 100 \mathrm{ml}(\mathrm{P}<0.001)$. In cows' blood cells in winter $38-42 \%$ $(\mathrm{P}<0.001)$ of variations in the content of this element are due to the variability of indicators of nervous process strength.

In addition, it was found that in summer only $49 \%(\mathrm{P}<0.01)$ of variations in the ratio of the lithium content in blood serum to blood cells in cows might be caused by the balance of nervous processes. Therefore, when the indicator of 
4. Multivariate analysis of variance of the influence of higher nervous activity type and the season on the lithium content in blood of cows

\begin{tabular}{|c|c|c|c|c|c|c|}
\hline Source of variation & SS & $\mathrm{df}$ & MS & $\mathrm{F}$ & P-value & F-test \\
\hline \multicolumn{7}{|c|}{ Blood serum } \\
\hline Higher nervous activity type & 0.0491 & 3 & 0.0164 & 13.2 & $<0.001$ & 3.01 \\
\hline Season & 0.0001 & 1 & 0.0001 & 0.09 & 0.766 & 4.26 \\
\hline Correlation & 0.0024 & 3 & 0.0008 & 0.63 & 0.600 & 3.01 \\
\hline Internal & 0.0298 & 24 & 0.0012 & & & \\
\hline Total & 0.0814 & 31 & & & & \\
\hline \multicolumn{7}{|c|}{ Whole blood } \\
\hline Higher nervous activity type & 0.0348 & 3 & 0.0116 & 14.8 & $<0.001$ & 3.01 \\
\hline Season & $<0.001$ & 1 & $<0.001$ & 0.003 & 0.952 & 4.26 \\
\hline Correlation & 0.0019 & 3 & 0.0006 & 0.822 & 0.495 & 3.01 \\
\hline Internal & 0.0188 & 24 & 0.0008 & & & \\
\hline Total & 0.0556 & 31 & & & & \\
\hline \multicolumn{7}{|c|}{ Blood cells } \\
\hline Higher nervous activity type & 0.0132 & 3 & 0.0044 & 23.1 & $<0.001$ & 3.01 \\
\hline Season & $<0.001$ & 1 & $<0.001$ & 0.066 & 0.799 & 4,26 \\
\hline Correlation & 0.0004 & 3 & 0.0001 & 0.637 & 0.598 & 3.01 \\
\hline Internal & 0.0046 & 24 & 0.0002 & & & \\
\hline Total & 0.0181 & 31 & & & & \\
\hline
\end{tabular}

nervous processes balance changes by one unit, the ratio of the lithium content in blood serum to blood cells changes in the same way by $0.012 \mathrm{CU}(\mathrm{P}<0.01)$.

The results of the multivariate analysis of variance of the influence of the higher nervous activity type and the season on the lithium content in blood of cows are shown in Table 4.

A significant dependence between the type of higher nervous activity in cows and the lithium content in blood se$\operatorname{rum}(\mathrm{F}=13.2>\mathrm{FU}=3.01 ; \mathrm{P}<0.001)$, whole blood $(\mathrm{F}=14.8>\mathrm{FU}=3.01$; $\mathrm{P}<0.001)$, and blood cells $(\mathrm{F}=23.1>\mathrm{FU}=3.01 ; \mathrm{P}<0.001)$ was found. The season, in contrast to the type of nervous system in cows, does not have a significant effect on the lithium content in different blood fractions.
Based on the results of the analysis of variance of the lithium content in different blood fractions in cows, no significant interaction between the typological features of the nervous system and the season has been established.

\section{Conclusions and future perspectives}

A significant dependence between the cows' type of higher nervous activity and the lithium content in blood serum $(\mathrm{F}=13.2>\mathrm{FU}=3.01 ; \mathrm{P}<0.001)$, whole blood $(\mathrm{F}=14.8>\mathrm{FU}=3.01 ; \mathrm{P}<0.001)$, and blood cells $(\mathrm{F}=23.1>\mathrm{FU}=3.01$; $\mathrm{P}<0.001$ ) has been established. In cows with a weak type of higher nervous activity, the lithium content in blood serum and its cells was lower by $12.1 \%$ 
$(\mathrm{P}<0.05)$ and $18.0 \%(\mathrm{P}<0.05)$, respectively, as compared with the indicators in cows with a strong balanced mobile type. Prospects for further research consist in the development of modern tools and methods for correcting the content of macro- and micronutrients in cows' blood, considering the individual characteristics of their nervous system.

\section{References}

Avtsyn, A. P., Zhavoronkov, A. A., \& Risch, M. A. (1991). Mikrojelementozy cheloveka jetiologija, klassifikacija, organopatologii [Human microelementoses. etiology, classification, organopathology]. Moskow: Medycina.

Byts, H. O. (2010). Vykorystannja preparativnogo germanii $v$ profilaktike gastrojenterivitov teljat [Vykorystannia preparativ hermaniiu $v$ profilaktytsi hastroenterytiv teliat]. Scientific Messenger of LNU of Veterinary Medicine and Biotechnologies. Series: Veterinary Sciences, 12(3(45)), 3-6. Vlizlo, V. V., Fedoruk, R. S., \& Ratych, I. B. (2012). Laboratorni metody doslidzhen u biolohiyi, tvarynnytstvi ta veterynarniy medytsyni [Laboratory methods of investigation in biology, stock-breeding and veterinary]. Spolom, Lviv.

Gromova, O. A., Torshin, I. Ju., \& Hadzhidis, A. K. (2010). Analiz molekuljarnyh mehanizmov vozdejstvija zheleza (II), medi, marganca v patogeneze zhelezodeficitnoj anemii [Analysis of the molecular mechanisms of the effects of iron (II), copper, manganese in the pathogenesis of iron deficiency anemia]. Klinicheskaia farmakologiia i farmaekonomika, 1, 1-9. Gapon, V. O., \& Yashchenko, A. B. (2005). Marganec' u navkolishn'omu seredovishhi ta jogo vpliv na organizm [Manganese in the middle of the middle of the yoke for organism]. Dovkillya zdorovia, 2(33), 69-72.

Guyot, H., Klinkon, M., Jezek, J., \& Staric, J. (2012). Diagnostika deficita mikrojelementov u zhvachnyh zhivotnyh [Trace minerals deficiency diagnosis in ruminants], In Proceedings of the 14th Conference of the European Society of Veterinary Clinical Pathology, 45-50.

Grushanska, N., \& Kostenko, V. (2017). The biochemical indicators of sows' blood at the prevention of mineral metabolic disorders. Scientific Messenger of LNU of Veterinary Medicine and Biotechnologies. Series: Veterinary Sciences, 19(82), 71-76. doi: $10.15421 /$ nvlvet8215

Danchuk, O. V., Karpovskyi, V. I., Trokoz, V. O., \& Postoi, R. V. (2017). Regulation mechanisms of cortisol level in pigs' blood serum under stress. Fiziolohichnyi zhurnal, 63(6), 60-65.

Zakharenko, M. O. (2004). Rol' mikroelementiv u zhittedijal'nosti tvarin [The role of microelements in living creatures]. Veterynarna medycyna Ukrainy, 2, 13-16.

Zinko, H. (2017). Immunnyj status teljat, bol'nyh gazotrojenteritom [Immune status of calves sick with gas-troenteritis]. Scientific Messenger of LNU of Veterinary Medicine and Biotechnologies, 19(82), 61-65. doi: $10.15421 /$ nvlvet8213.

McDowell, L. R. (2003). Minerals in animal and human nutrition (No. Ed. 2). Elsevier Science BV. doi: 10.1016/B978-0-444-51367-0.X5001-6.

Kalyn, B. M. (2011). Zastosuvannja helatnyh spoluk mikrojelementiv u hodivli tvarin. Metodicheskie rekomendacii [The use of chelated compounds of trace elements in animal nutrition. Methodical recommendations]. Lviv.Marushko, Yu. V. (2013). Znachennja porushen' vmistu margancju u klinichnij praktici [Significant damage to the city Manganese in Clinical Practice]. Childrenss doctor, 4(25).

Pogorlov, M. V. (2010). Makro- ta mikroelementi (obmin, patologija ta metodi viznachennja): monografija [Macro of microelements (exchange, pathology and methodology): monograph]. Sumy: SUMDU.Skalny, A. V. (2004). Himicheskie jelementy v fiziologii i jekologii cheloveka [Chemical elements in physiology and ecology person]. Moscow: ONICS 21 century World. 
О. В. Журенко, В. І. Карповський, В. В. Журенко. (2021). КОРТИКАЛЬНІ МЕХАНІЗМИ РЕГУЛЯЦІЇ ВМІСТУ ЛІТІЮ В КРОВІ КОРІВ ЗАЛЕЖНО ВІД ПОРИ

РОКУ. Ukrainian Journal of Veterinary Sciences, 12(1): 51-59,

https://doi.org/10.31548/ujvs2021.01.006

Анотація. Поведінка сільськогосподарських тварин, а особливо великої рогатої худоби, $\epsilon$ важливою господарсько-корисною ознакою, що значно полегшує умови експлуатації та виробництва продукції тваринництва. Параметри нервової системи великої рогатої худоби визначають ії поведінку в різних ситуаціях, зокрема, в загоні, вигулі, під час доїння. Оптимальний вміст мінеральних речовин в організмі зумовлює нормальний перебіг процесів метаболізму і високу продуктивність. За результатами дослідження умовно-рефлекторної діяльності було сформовано чотири дослідні групи. Для лабораторного аналізу використовували чільну кров, сироватку, плазму та клітини крові. За результатами дисперсійного аналізу вмісту Літію в різних фракціях крові корів вірогідну взаємодію між типологічними особливостями нервової системи та порою року не встановлено. Рухливість нервових процесів незалежно від пори року вірогідно пов'язана з вмістом Літію в чільній крові, клітинах крові та сироватці крові $(r=0,15-0,22)$. Водночас показник трансмембранного потенціалу за Літієм (Lіклітин) Lісироватки) вірогідно повяязаний лише із силою та врівноваженістю нервових процесів у корів у теплу пору року $-r=0,62-0,76(P<0,05-0,01)$.

Встановлено вірогідну залежність від типу вищої нервової діяльності корів та вмісту Літію в сироватиі крові $(F=13,2>F U=3,01 ; P<0,001)$, чільній крові $(F=14,8>F U=3,01$; $P<0,001)$ та клітинах крові корів ( $F=23,1>F U=3,01 ; P<0,001)$. Укорів зі слабким типом ВНД вміст Літію в сироватиі крові та ії клітинах був меншим відповідно на 12,1\% $(P<0,05)$ та $18,0 \%(P<0,05)$ порівняно до показників корів із сильним врівноваженим рухливим типом.

Ключові слова: вища нервова діяльність, макроелементи, типи вищої нервової діяльності 